$<$ 原 著 $>$

老年者発作性心房細動患者の虚血性脳血管障害発症率に関する研究

中島 一夫 一之瀬正彦

<要 約 > 目的：65歳以降発症の発作性心房細動例 (E-PAf) の虚血性脳血管障害 (iCVD) 発症率を 65歳以前発症の発作性心房細動例 (Y-PAf) 及び65歳以降発症の慢性心房細動例 (E-CAf) の発症率と比 較し, その特徵を検討した。

対象及び方法：対象は, 弁膜症を有さず, 予防的抗凝固療法未施行の E-PAf 95例(男54, 女41, 73.6土

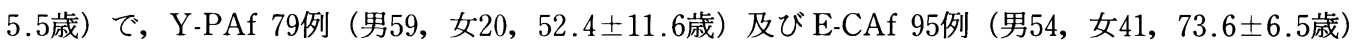
を対照として, 後向き調查にて $\mathrm{iCVD}$ 全体及び成因別（脳血栓症, 脳塞栓症）の発症率を算出した。

結果：E-PAf は平均観察期間 45.0 力月で, $\mathrm{iCVD}$ 発症率は年間 $4.8 \%$ (塞栓 $2.7 \%$, 血栓 $2.1 \%$ ), Y-PAf は 48.0 カ月で年間 $2.5 \%$ (塞栓 $1.3 \%$, 血栓 $0.6 \%$, 分類不能な梗塞 $0.6 \%$ ), E-CAf は 59.8 カ 月で年間 $8.3 \%$ (塞栓 $5.1 \%$, 血栓 $1.9 \%$, 分類不能な梗塞 $1.3 \%$ ) であった。 iCVD 全体の発症率で, E-PAf は E-CAf ょ り有意に低率 $(\mathrm{p}<0.01)$, Y-PAf より有意に高率 $(\mathrm{p}<0.01)$, 脳塞栓症発症率でも, E-PAf は E-CAf よ り有意に低率 $(\mathrm{p}<0.01)$, Y-PAf より有意に高率 $(\mathrm{p}<0.01)$, 脳血栓症発症率では, E-PAf はY-PAf よ り有意に高率 $(\mathrm{p}<0.01)$ であった。

E-PAf 中, 1 回のみの Af 発作57例と複数回発作 38 例間で，iCVD 発症率（年間 $3.3 \%$ v.s. $6.0 \%$ ）及 び脳塞栓症発症率（年間 $0.8 \%$ v.s. $4.6 \%$ ） は複数回例で有意に高率 $(\mathrm{p}<0.005)$, 一方, 脳血栓症発症 率（年間 $2.5 \%$ v.s. $1.4 \%$ ） は有意差なし.

E-PAf 中21例 (22\%) が慢性に移行し，移行後，iCVD 全体で 5 例 (年間発症率 $8.6 \%$ )，その中，脳塞 栓症は 3 例（年間発症率5.2\%）に生じた.

結語：老年発症発作性心房細動群の虚血性脳血管障害及び脳塞栓症発症率は, 老年発症慢性心房細動 群と若年発症発作性心房細動群の中間に位置し, 複数回の心房細動発作及び心房細動の慢性化が発症率 をさらに上昇させる因子になると考えられた。

Key words：発作性心房細動，慢性心房細動，虚血性脳血管障害, 脳塞栓症, 脳血栓症

\section{緒 言}

慢性非弁膜症性心房細動例の虚血性脳血管障害 (iCVD) 発症に関しては非常に多くの報告が存在し， 一般には洞調律例に比し約 $4 \sim 6$ 倍の発症率を有する といわれている.

一方, 発作性心房細動例については, 多数例を長期 間観察することが慢性心房細動例ほど容易でないた め, 発作性心房細動例の iCVD 発症についての解析は 末だ充分になされているとはいえない.

今回, 弁膜症を有しない老年者発作性心房細動例の $\mathrm{iCVD}$ 発症率を成因別に算出し, 若年者発作性心房細

K. Nakajima, M. Ichinose：佐久市立国保浅間総合病 院内科

受付日：1995.12.20，採用日：1996.2．7

第37回日本老年医学会学術集会推薦論文
動及び老年者慢性心房細動例の発症率と比較すること により，その特徵を明らかにしょうとした。

\section{対象及び方法}

対象は1984年 1月から1994年12月迄に来院し， 6 力 月以上経過観察され, 弁膜症を有さず, 予防的抗凝固 療法未施行の65歳以降発症（老年者）発作性心房細動 (E-PAf) 95例である. 性比は男性が54例, 女性が41例, 平均年齢は73.6 5 5.5歳であった。 また, 65 歳以前発症 （若年者）発作性心房細動（Y-PAf）79例（男59例, 女 20例, 52.4 11 . 6 歳) 及び E-PAf と年齢 2 歳以内, 基礎心疾患及び糖尿病の有無を一致させた老年者慢性 心房細動（E-CAf）95例（男54例, 女41例, $73.6 \pm 6.5$ 歳)を対照群とした。

各心房細動（Af）群の基礎心疾患及び合併疾患を表 1 に示す. 高血圧合併率は E-PAf（E-CAf）群で65\% 
表 1 各 Af 群の基礎心疾患及び基礎疾患合併頻度

\begin{tabular}{c|c|c|c|c|c|c|c|c}
\hline & 高血圧 & 虚血性 & 心筋症 & MVP & SSS & 甲状腺 & 糖尿病 & 高脂血症 \\
\hline E-PAf & $65 \%$ & $17 \%$ & $0 \%$ & $2 \%$ & $5 \%$ & $2 \%$ & $21 \%$ & $4 \%$ \\
\hline Y-PAf & $43 \%$ & $11 \%$ & $1 \%$ & $4 \%$ & $3 \%$ & $11 \%$ & $18 \%$ & $5 \%$ \\
\hline E-CAf & $65 \%$ & $17 \%$ & $0 \%$ & $2 \%$ & & $2 \%$ & $21 \%$ & $4 \%$ \\
\hline
\end{tabular}

E-PAf : 65歳以上の発作性心房細動 MVP : 僧帽弁逸脱症候群

Y.PAf：65歳未満の発作性心房細動 S S S : 洞機能不全症候群

E-CAf : 65歳以上の慢性心房細動甲甲状腺：甲状腺機能穴進症

と Y-PAf 群の $43 \%$ より高率, 虚血性心疾患合併率も E-PAf 群で17\%とY-PAf 群の11\%より高率であっ た。筋症, 僧帽弁逸脱症候群, 洞機能不全症候群の 合併率は 0 〜 \% と各群で差はなかった。 甲状腺機能 穴進症合併率はY-PAf 群で11\%と有意に高率. 糖尿 病, 高脂血症合併率は各群で差はなかった。

$\mathrm{iCVD}$ 発症率は, 後向き調査にて,（観察期間中の発 症数）（回） $\div$ (総観察期間）（力月） $\times 12 \times 100$ の計算式 を用い，年間発症率 (回/年) で表した. 予防的に抗血 小板剂が投与されている例は除外しなかったが，これ らの例では抗血小板剤服用期間は観察期間に含まれて いない. 再発予防目的で抗凝固療法または抗血小板療 法が開始された場合も同様に扱った。また，Y-PAf 群 が65歳に達した場合, それ以降は観察期間に含めてい ない.

iCVD は可能な限り塞栓症か血栓症に分類したが, 分類不能例は分類不能な梗塞症とした。脳塞栓症の診 断は既報告の診断基準 ${ }^{1}$ に準じた。脳血栓症は，しばし ば一過性脳虚血発作を伴い, 神経症候は緩徐に完成, 頭部 CT (MRI) にて穿通枝領域に限局する小・中梗塞 と定義した。但し，皮質を含む梗塞の場合は，脳塞栓 症の診断基準を満たさず，慢性期脳血管造影にて当該 血管に閉塞·狭窄病変を認めた場合のみ血栓症とした。 有意差判定は $\chi^{2}$ 検定および $\mathrm{t}$ 検定にて行った。

\section{成 績}

1. E-PAf 群と Y-PAf 群の iCVD 発症率（図 1)

平均観察期間は, E-PAf 群で45.0カ月, Y-PAf 群で 48.0カ月であった。

$\mathrm{iCVD}$ 全体の発症率は E-PAf 群が4.8\%/年で, Y$\operatorname{PAf}$ 群 $(2.5 \% /$ 年 $)$ より有意に高率であった（p< $0.01)$.

成因別では, 脳塞栓症発症率は E-PAf 群 $(2.7 \% /$ 年) が Y.PAf 群（1.3\%/年）より有意に高率（ $\mathrm{p}<0.01 ）$,

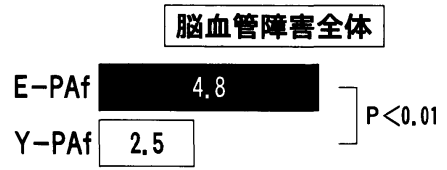

\begin{tabular}{|l|l|}
\hline 脳塞栓症脳血栓症 \\
\hline
\end{tabular}

脳梗塞症

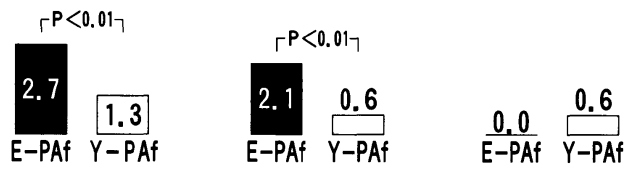

図 1 E-PAf 群及び Y-PAf 群の虚血性脳血管障害発 症率. 虚血性脳血管障害全体, 脳塞栓症及び脳血栓 症発症率のいずれも, E-PAf 群はY.PAf 群より有 意に高率

脳血栓症発症率でも E-PAf 群 (2.1\%/年) が Y-PAf 群 $(0.6 \% /$ 年）より有意に高率であった（ $<<0.01 ）$.

2. E-PAf 群と E-CAf 群の iCVD 発症率（図 2)

平均観察期間は, E-PAf 群で45.0力月, E-CAf 群で 59.8カ月であった。

$\mathrm{iCVD}$ 全体の発症率は E-PAf 群が4.8\%/年で, E$\mathrm{CAf}$ 群の $8.3 \% /$ 年より有意に低率であった（p< $0.01)$.

成因別では, 脳塞栓症発症率は E-PAf 群 $(2.7 \% /$ 年) は E-CAf 群 $(5.1 \% /$ 年) より有意に低率 $(\mathrm{p}<0.01)$ で あったが，脳血栓症発症率では E-PAf 群と E-CAf 群 間に有意差は存在しなかった (2.1 v.s. 1.9\%/年).

3. E-PAf 群での Af 発作回数別による iCVD 発症 率 (図 3 )

Af 発作回数別にみると 1 回のみ例は 57 例, 複数回例 は38例存在した．表 2 に示すように 1 回のみ例で男性 が高率, 複数回例で僧帽弁逸脱症候群合併率が高率で あったが，年齢，高血圧，虚血性心疾患，洞機能不全 

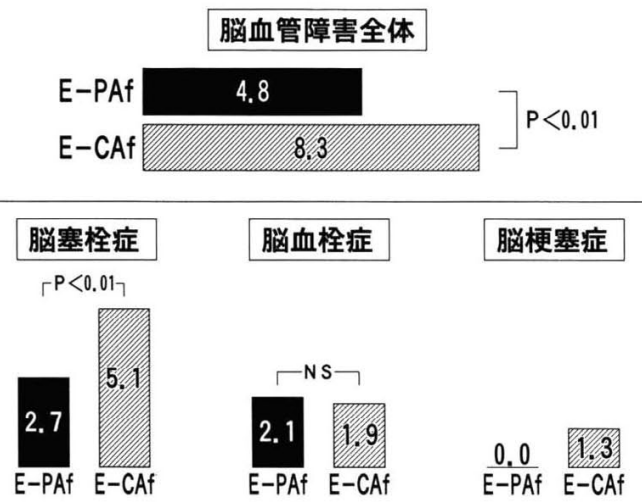

図 2 E-PAf 群及び E-CAf 群の虚血性脳血管障害発 症率. 虚血性脳血管障害全体及び脳塞栓症発症率に おいて, E-PAf 群は E-CAf 群より有意に低率
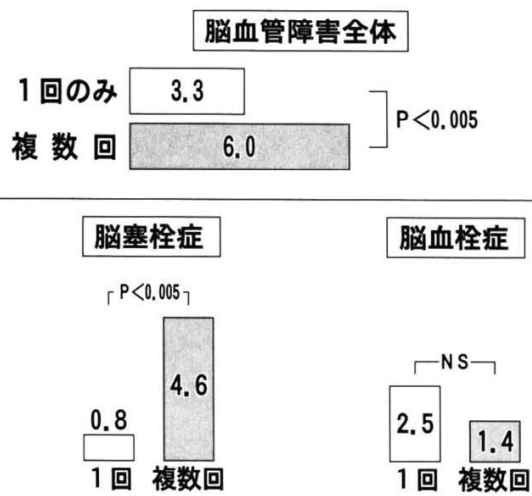

図 3 E-PAf 群におけるAf 発作回数別の虚血性脳血 管障害発症率，虚血性脳血管障害全体及び脳塞栓症 発症率において, 複数回発作例は 1 回発作例より有 意に高率

症候群, 甲状腺機能六進症及び糖尿病合併率に差はな かった。

複数回例は 1 回例に比し，有意に $\mathrm{iCVD}$ 全体 $(6.0 \mathrm{v}$. s. $3.3 \% /$ 年) 及び脳塞栓症発症率 (4.6 v.s. $0.8 \% /$ 年) が高率であった $(\mathrm{p}<0.005)$ 。脳血栓症発症率は両者に 有意差は存在しなかった（1.4 v.s. $2.5 \% /$ 年).
4. E-PAf 群の Af 慢性化例と iCVD 発症

E-PAf 95例中21例（22\%）が慢性 Afに移行したが, 発作性 Af 発症から慢性移行への期間は平均 28.9 力月 （1～96力月）であった.

慢性 Af 移行後, 平均34.6力月の観察で, iCVD は全 体で 5 例 (年間発症率 $8.6 \%$ ) に生じた. 脳塞栓症は 3 例 (年間発症率 $5.2 \%$ ) で, 慢性移行後の $1,1,3$ 力 月後の早期に生じた。脳血栓症及び分類不能な脳梗塞 症はそれぞれ 1 例（年間発症率1.7\%）に発症した。

\section{考 察}

Petersen ${ }^{2)}$, Cairns ら ${ }^{3)}$ は Af 例の脳血管障害に関す る文献を総括し, 発作性 Af は慢性 Af に比し塞栓症発 症率は低率だが，年齢を一致させた洞調律群の発症率 より高率であると述べた。

Halperin ら ${ }^{4}$ は60歳以下の発作性 Af 例は脳血管障 害発症低リスク群 $(<3 \% /$ 年) に入るが，60歳以上の 発作性 Af 例及び慢性 Af 例は発症高・低リスク群のい ずれにも属さないと報告した。

著者らも同様な検討を行( ${ }^{1)}, 60$ 歳末満の発作性 Af 40 例の虚血性脳血管障害発症率は 1.37 回/100人・年で 発症低リスク群に分類したが，60歳以上の発作性 Af 93例及び60歳以上の慢性 Af 93例の発症率はそれぞれ 3.98 回/ 100 人・年， 5.08 回/ 100 人・年で発症中間リス ク群に分類した。

Shimomura ら ${ }^{5)}$ は非りウマチ性発作性 Af 109例 (平 均年龄56歳）の全身塞栓症発症率は 1.6 回/ 100 人・年, 慢性 Af 181例（平均年齢62歳）の発症率は1.2回/100 人・年と報告した.

庄田ら ${ }^{6)}$ は非りウマチ性発作性 Af 124例（抄録のた め平均年齢は不明)を平均 6.1 年間観察し，その虚血性 脳血管障害発症率は $2.6 \% /$ 年で, 慢性 Af 118例の $3.3 \% /$ 年と有意差はなかったが, 洞調律群 88 例の発症 率（1.1\%/年）より有意に高率であったとした。また， 発作性 Af 群では70歳以上で発症率が高值であったと 述べた。

本報告では, 虚血性脳血管障害全体の発症率では,

表 2 E-PAf 群における Af 発作回数別の患者テ゚ロフィール

\begin{tabular}{l|c|cc|c|c|c|c|c|c|c}
\hline Af 発作 & 総数 & 男 & 女 & 平均年歯 & 高血圧 & 虚血性 & MVP & SSS & 甲状腺 & 糖尿病 \\
\hline 1 回のみ & 57 例 & 35 & 22 & 73.1 & $65 \%$ & $18 \%$ & $0 \%$ & $5 \%$ & $2 \%$ & $23 \%$ \\
\hline 複数回 & 38 例 & 19 & 19 & 74.0 & $66 \%$ & $16 \%$ & $5 \%$ & $5 \%$ & $3 \%$ & $18 \%$ \\
\hline
\end{tabular}


老年者発作性 Af $(4.8 \%$ /年) は老年者慢性 Af $(8.3 \%$ / 年) と若年者発作性 Af (2.5\%/年) の中間に位置し, 脳塞栓症発症率でも, 老年者発作性 Af $(2.7 \% /$ 年) は 老年者慢性 Af $(5.1 \% /$ 年) と若年者発作性 Af (1.3\%) 年）の中間に位置した。一方, 脳血栓症発症率では, 老年者発作性 Af $(2.2 \%$ / 年) は老年者慢性 Af (1.9\%) 年）と有意差なく, 若年者発作性 Af $(0.6 \% /$ 年) より も高率であった。

これらの報告を加味して考えると, 虚血性脳血管障 害全体及び脳塞栓症発症率は, 老年者慢性 $\mathrm{Af}$ 群>老 年者発作性 $\mathrm{Af}$ 群>若年者発作性 $\mathrm{Af}$ 群>洞調律群と いえるのではないかと著者らは考える.

Af 例での脸塞栓症の大部分は左房内血栓に起因す るものと思われる. 当院での弁膜症を有しない慢性 Af 41例の TAT 及び D-dimer を測定した成績 (末発表) では, TAT 及び D-dimer がともに高值の例は22例, い ずれか高值の例を含むと全体で32例となり，その中， 経食道心エコー法にて左房内血栓は10例, モヤモヤエ コーは27例に認められた。一方, 発作性 Af 群では, Af 発症16時間後の群は, 発症 6 時間の群, 洞調律群より 有意に TAT が高值であったという報告7)がある。慢 性 Af では常に血栓準備状態にある, 発作性 Af ではあ る程度発作が持続すると血栓準備状態となる, 洞調律 では血栓準備状態にほとんどないことが, 左房内血栓 陽性率ひいては脳塞栓症発症率の差になると考えられ る.

老年者発作性 $\mathrm{Af}$ 群と若年者発作性 $\mathrm{Af}$ 群の比較で は, 加齢, 高血圧・糖尿病 - 虚血性心疾患の罹患率の 差が脳血栓症発症率の差に反映されたと思われる。脳 塞栓症に関しては, 年齢による凝固線溶穴進の差, 発 作持続時間の差などが想定されるが，今後の検討が必 要であろう。

また，老年者発作性 Af では発作回数が複数回にな ると虚血性脳血管障害全体および脳塞栓症発症率はそ れぞれ $6.0 \% /$ 年, $4.6 \% /$ 年に, また, 慢性 Afに移行す ると発症率はそれぞれ $8.6 \% /$ 年, $5.2 \% /$ 年と高率に なった.さらに脳塞栓症は慢性移行 $1,1,3$ 力月後 の早期に生じた点も注目に值する.
Petersen $ら^{8)}$ は, 発作性 Af から慢性 Afに移行した 141 例の平均 9.0 年の検討にて, 慢性に移行した最初の 1 年間の脳塞栓症発症率は $13.3 \%$ とその後 4 年間の約 $4 \% /$ 年より明らかに高率であるとした。

繰り返す老年者発作性 Af 例では，まず適切な抗不 整脈剂にて発作頻度の減少及び慢性化を予防する試み が必要であり, 抗不整脈剤の効果が得られない場合は 積極的に抗凝固療法も考慮すべきと考えられた。

本論文の要旨は, 第37回日本老年医学会総会にて発表し た.

\section{文献}

1）中島一夫,一八瀬正彦, 高田進一：心房細動患者の 虚血性脳血管障害に関する研究. 日老医誌 1995 ; $32:$ 497-502.

2) Petersen P: Thromboembolic complications in atrial fibrillation. Stroke $1990 ; 21: 4-13$.

3) Cairns JA, Connolly SJ : Nonrheumatic atrial fibrillation. Risk of stroke and role of antithrombotic therapy. Circulation $1991 ; 84: 469-$ 481.

4) Halperin JL, Hart RG: Atrial fibrillation and stroke: New ideas, persisting dilemmas. Stroke $1988 ; 19$ : 937-941.

5) Shimomura $K$, Ohe T, Uehara S, Matsuhisa M, Kamakura S, Sato I: Significance of atrial fibrillation as a precursor of embolism. Am J Cardiol 1989; 63: 1405-1407.

6) 青木 晶, 庄田守男, 岩出和徳, 笠貫 宏, 楠元雅 子, 細田瑳一: 発作性心房細動は脳梗塞発症の危 険因子となるか？Jpn Circ J 1994； 58 (Suppl 1)： 327.

7）曾原 寛, 黒瀬満郎, 宮原健吉：発作性心房細動 (PAF) にわける凝固・線溶動態一発作持続時間と の関連一. Jpn Circ J 1995; 59 (Suppl 1): 530.

8) Petersen P, Godtfredsen J : Embolic complications in paroxysmal atrial fibrillation. Stroke $1986 ; 17: 622-626$. 
Abstract

\title{
Ischemic Stroke in Elderly Patients with Paroxysmal Atrial Fibrillation
}

\author{
Kazuo Nakajima and Masahiko Ichinose
}

We compared the rate of ischemic strokes in elderly patients (those aged 65 years or more) who had paroxysmal atrial fibrillation (E-PAf) with those of younger patients (less than 65) with paroxysmal atrial fibrillation (Y-PAf) and of elderly patients with chronic atrial fibrillation (E-CAf) in a retrospective study. A total of 95 E-PAf patients (mean age 73.6), 79 Y-PAf patients (mean age 52.4), and 95 E-CAf patients (mean age 73.6) were studied. The incidence of all ischemic strokes in E-PAf patients $(4.8 \% / \mathrm{yr})$ was significantly lower than in E-CAf patients $(8.3 \% / y r)$ and higher than in Y-PAf patients $(2.5 \% / \mathrm{yr})(\mathrm{p}<.01)$. We found the same tendency in the occurrence of brain embolism. Brain embolism occurred in $2.7 \%$ of E-PAf patients per

Department of Internal Medicine, Asama General Hospital year which was significantly lowre than in E-CAf patients $(5.1 \% / \mathrm{yr})$ and higher than in Y-PAf patients $(1.3 \% / \mathrm{yr})(\mathrm{p}<.01)$. E-PAf patients suffered more brain thrombosis than Y-PAf patients, but they had nearly the same incidence as did E-CAf patients. Fifty-seven E-PAf patients had only one attack of atrial fibrillation and the remaining $38 \mathrm{had}$ more than two attacks. Patiens with many attacks of atrial fibrillation had significantly higher rate of brain embolism than did those who had only one attack $(4.6$ v.s. $0.8 \% / \mathrm{yr}) \quad(\mathrm{p}<.005)$. Those two groups did not differ with regard to the rate of brain thrombosis.

Key words: Paroxysmal atrial fibrillation, Elderly patients, Stroke rate, Brain embolism, Brain thrombosis

(Jpn J Geriat 1996; 33: 273-277.) 